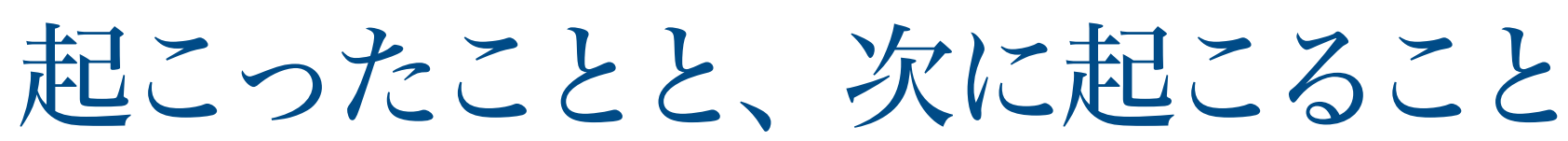

\title{
What happened and what's next?
}

\author{
Kerry Sieh
}

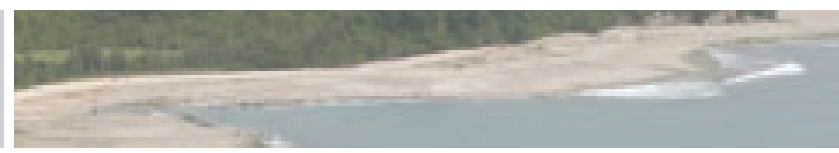

2004 年 12 月 26 日に起こった大地震とそれがもたらした津波は、インドネシアのアチェ沖から アンダマン諸島に向けて海底が裂けたことが原因だった。この時の状況が明らかになりつつある。 Nature Vol.434(573-574)/31 March 2005

2004 年の年末に起きたアチェーアンダマン地震と大津波 では本当にたくさんの人が翻弄された。そして一般人か ら科学者までが先を争って、地球の地殼と海にいったい 何が起きたのかを解明しょうとし始めた。主震のほんの 数時間後に得られた最初期の情報の 1 つは、北スマトラ からミャンマー (ビルマ) に至る弧状で $1,300 \mathrm{~km}$ に及 ぶ大きな余震帯の図だった1。これは、インド・オース トラリアプレートが東南アジアの下に沈み込み始める場 所である巨大な地殼の境界、スンダ巨大断層の約 $25 \%$ が 動いた証拠のように思われる。だが 1 日とたたない内に、 地震の「実体」波を解析したところ動いた断層の長さは 約 $400 \mathrm{~km}$ にすぎないという報告が出された ${ }^{2}$ 。

巨大断層内の動いた断層の長さに関して最初のころ見 られた意見の食い違いは、将来起きる可能性のある危 険の程度がはっきりしないため、ベンガル湾周辺の住民 に不安を与えた。巨大断層の内の $400 \mathrm{~km}$ だけが動いた とするならば、まだ動いていない部分が残っているため にさらなる津波が起きる可能性がある。逆に、海底の断 層のほとんどが動いていたなら、その可能性は非常に小 さい。

$\mathrm{Ni}$ らは、初期の解析で動いた断層の長さがかなり短く 見積もられた理由を説明し、周波数の高い $(2 \sim 4 \mathrm{~Hz})$ 地震波信号を解析した結果、動いた断層はあきらかに北 方へ約 1,200 km にわたって広がっていると報告してい る (原著論文は $3 / 31$ 号 p.582 を参照のこと ) ${ }^{3}$ 。また、 Stein と Okal は地震のマグニチュードに関する初期の推 定值 ${ }^{1,2}$ はあまりにも小さすぎたと主張している (同 p.581 参照 $)^{4}$ 。極めて周期の長い「正規モード」の地震波を用 いて算定すると、地震のマグニチュードは 9.3 となり、 初期の推定值である 9.0 よりも（地震のマグニチュード
の尺度は対数の性質を持つことを考慮に入れると） 3 倍 大きかったという。すべりのほとんどが非常にゆっくり 起きたため波長の短い地震動の記録には現れなかったの だと仮定すれば、このように極めて大きい地震の規模と、 長さ $1,200 \mathrm{~km}$ にわたる断層に沿って起きた平均して約 $13 \mathrm{~m}$ のすべりの事実は整合する。したがつて、動いた 断層の長さに関する意見の違いは解決され、この長い断 層沿いで別の巨大地震と津波が起きる可能性を心配する 必要はないと彼らは主張する。

今回の 2 つの報告 ${ }^{3,4}$ は、今世紀もつとも重要な地震 の1つに数えられることが確実な今回の地震に関して発 表された、最初の解析の一部である。今後 1 年か 2 年の 間は、何が起きたかを検討するのに新しい観測技術と解 析が駆使され、また最新の地球科学の学際的な研究が次々 となされるだろう ${ }^{5}$ 。数ヶ月後経てば、今回の地震につ いてもつと多くのことが分かり始めるはずだ。大きく隆 起・沈降した海岸線の衛星画像や現場計測（図 1） 6,7 、 全地球測位システムの測地点の動き 8 、さらに津波の記 録によって、各地域で動いた断層の広がりやマグニチュー ドの大きさ、そしてすべりの順序も絞り込める。これら は津波の解明においても欠くことのできないものだ。

スマトラ島最北端とミャンマーの間の巨大断層が動い て今回の千年に一度の巨大地震が起きたとするならば、 ベンガル湾で別の巨大地震と津波が近い将来起こる可能 性を懸念すべき理由はあるだろうか？ McCloskeyら は、2004 年の巨大な断層の動きによってさらに南にあ る2つの大きな断層に加えられた応力を推定し、1つの 回答を出した 9 。すぐ南にあるスンダ巨大断層のスマト ラ島北部沖の部分は今にも壊れそうに思える。バンダ・ アチェからスマトラ本島の山脈にかけて走るサンアンド 


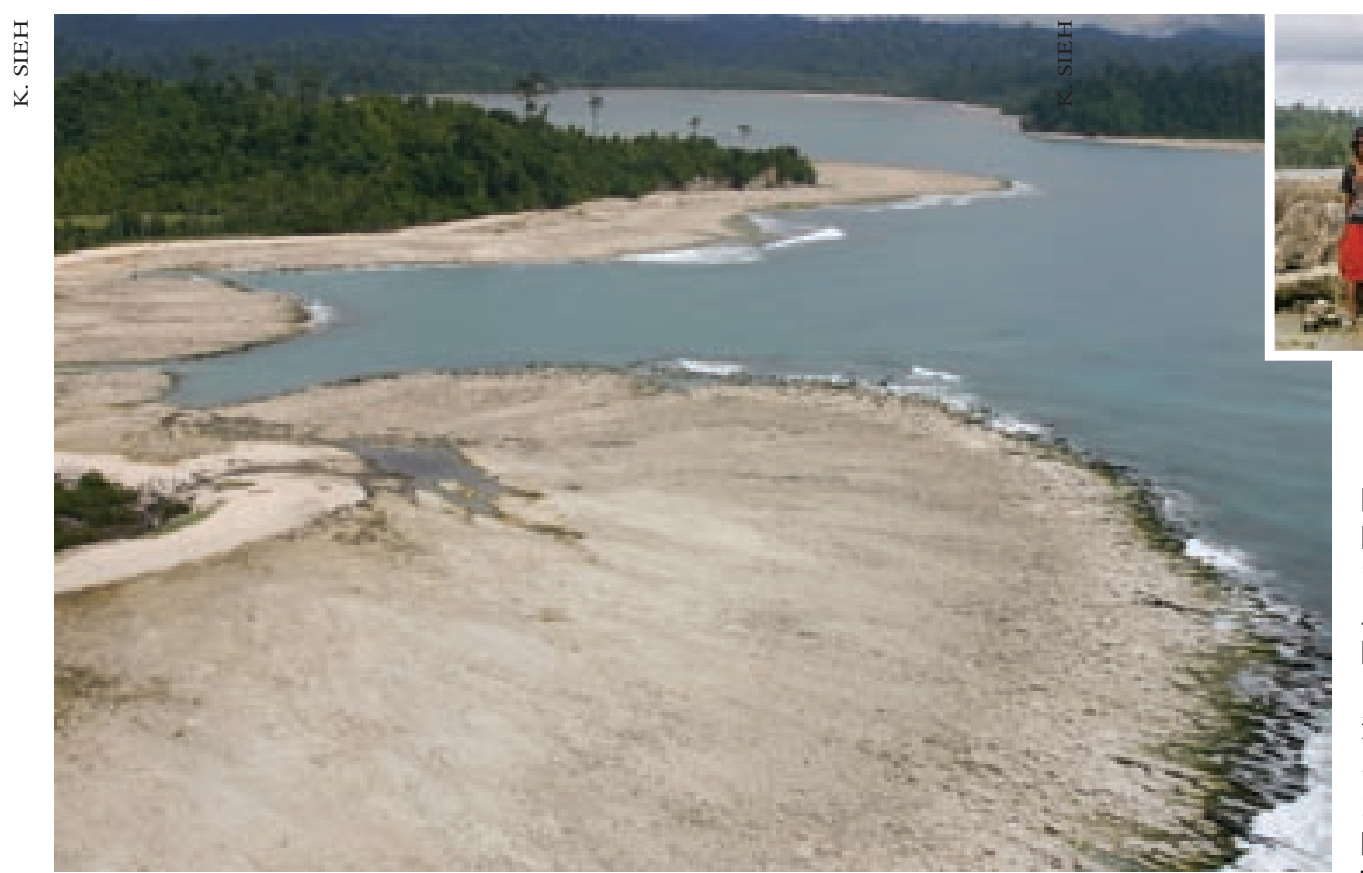

図 1 隆起の証拠一 ここでは約 $1.5 \mathrm{~m}$ 隆起した。この航空写真はアチェーアンダ マン地震を引き起こした巨大断層の南端 上にあるシメル島南西岸に現れた新しい 陸地を示している。幅の広い縞状の土地 はかつて珊瑚礁だったところで、かつて 海浜だった場所（図の最も左側）は高く なり乾いたままである。上図では元々あっ たサンゴが、地震の間に約 $1 \mathrm{~m}$ 隆起した 隣接するサンゴ礁とぶつかっている。

レアス断層に似たスマトラ断層にほど近い部分も同様で ある。

となると、2004 年に起こった断層の動きによってこ れら 2 つ断層が壊れる時期がどの程度早まったかが重 要な問題になってくる。しかし、これらの断層の過去の 歴史がもう少し詳しく明らかになるまでは実際のところ がわからないだろう。この巨大断層のスマトラ島部分が どのように構造的に分割されるのか、過去にどのような 動きがあったのかを知ることが必要だろう。たとえば、 2004 年に動いた断層のすぐ南では、歴史的な文献から 1861 年と 1907 年に大きな地震があったと思われる ${ }^{10}$ 。 これらの断層の動きは具体的に巨大断層のどこで起こっ たのか、そしてどの程度の頻度でどのくらい規則的に 繰り返されているのか？ 古地震のデー夕は、赤道の南 $1^{\circ}$ から $5^{\circ}$ というベンガル湾からは遠い長さ $700 \mathrm{~km}$ の 部分についてしか利用できない。この地域では巨大な地 震と津波が約 200 年から 230 年おきに、時には単一の巨 大地震として、時には 1797 年と 1833 年に起きたような 比較的間隔の短い 2 つの連続した地震として起こってい る ${ }^{11,12}$ 。

2004 年に動いた断層の北側にある大断層もまた危険 である。この断層は北へさらに $1,000 \mathrm{~km}$ 延びており、 ミャンマー西岸の北部からバングラデシュをかなり過ぎ たヒマラヤ山脈の東端まで続いている。その長い歴史の ほとんどは知られておらず、将来起こるふるまいについ て意味ある評価はできない。さらに、インドがヒマラヤ
山脈の下に沈み込んでいる巨大な衝上断層の長い部分は 数百年にわたって断層の動きがなく、2004 年に動いた 断層から 1 〜 断層長離れているだけである。

大きな地震が時には集中して起きることは覚悟されて よい（たとえば、20 世紀に 10 回発生した大地震のうち 7 回は 1950 年から 1965 年の間に起こっており、5 回は 北太平洋縁辺で起こっている）13。アチェーアンダマン近 辺の大断層の多くは非常に長いあいだ休眠状態だったの で、最近起こった巨大地震と津波がインドプレートの不 規則な北方への移動の結果として 21 世紀中に起きる唯 一の大災害だったわけではないと考えるのは決して間違 いではない。

カリフォルニア工科大学 (米)、Kerry Sieh

1. http://neic.usgs.gov/neis/poster/2004/20041226_image.html

2. www.gps.caltech.edu/ jichen/Earthquake/2004/aceh/aceh.html; www.eri. u-tokyo.ac.jp/sanchu/Seismo_Note (in Japanese).

3. Ni, S., Kanamori, H. \& Helmberger, D. Nature 434, 582 (2005).

4. Stein, S. \& Okal, E. A. Nature 434, 581-582 (2005).

5. Committee on the Science of Earthquakes Living on an Active Earth:

Perspectives on Earthquake Science (Natl Academies Press, Washington DC, 2002).

6. www.tectonics.caltech.edu/sumatra/main/data.html

7. Bilham, R. Preprint at http://cires.colorado.edu/ bilham

8. www.seires.net/content/view/122/52

9. McCloskey, J., Nalbant, S. S. \& Steacy, S. Nature 434, 291 (2005).

10. Newcomb, K. R. \& McCann,W. R. J. Geophys. Res. 92, 421-439 (1987).

11. Sieh, K., Natawidjaja, D., Chlieh, M., Galetzka, J. \& Avouac, J.-P. Trans. Am Geophys. Un. Fall Meet. Suppl. Abstr. T12B-04 (2004).

12. Zachariasen, J., Sieh, K., Taylor, F.W., Edwards, R. L. \& Hantoro,W. S. J. Geophys. Res. 104, 895-919 (1999).

13. Kanamori, H. Nature 271, 411 (1978). 